\title{
TRIPLE-ROLES PEREMPUAN PENGELOLA ART SHOP DI PANTAI SINDHU KELURAHAN SANUR DENPASAR SELATAN
}

\author{
Putu Ayu Puri Sintya Dewi a, 1, I Gst. Agung Oka Mahagangga a, 2 \\ 1puri.sintya@ymail.com,2ragalanka@gmail.com \\ a Program Studi S1 Destinasi Pariwisata,Fakultas Pariwisata,Universitas Udayana, Jl. Dr. R. Goris, Denpasar, Bali 80232 Indonesia
}

\begin{abstract}
Economic demands improve the role of women in public area. It makes women having double workload on domestic and public area. This study is located in Sindhu Beach, Sanur.. The type of data used is quantitative and qualitative data. Sources of data are primary data and secondary data. Data was collected by observation techniques, in-depth interviews, documentary studies and literature studies. Descriptive data were analyzed qualitatively. These studies find that productive roles are women involved as a worker by open souvenir shop in tourist destination. Women are empowered in decision-making on the management of art shop herself. Reproductive role of women such as cooking, shopping daily needs, washing cloth, cleaning house and babysitting. If they are too busy in art shop, they will buy some food in market for their family and bring their dirty cloth to laundry. Social or community role of women such as participate in Sindhu Art Market organization, Balinese people organization named 'banjar' and women organization in banjar. All the roles can be done because women manage their time well. If they have to participate in banjar activities, they close the art shop because they think the social role in banjar is more important.
\end{abstract}

Keywords: Triple Roles, Women, Art Shop

\section{PENDAHULUAN}

Sanur adalah salah satu ikon daya tarik wisata pantai yang terdapat di Kota Denpasar. Perkembangan pariwisata di Sanur dimulai sejak menetapnya pelukis asal Belgia bernama Andrien-Jean Le Mayeur de Mepres. Pesatnya arus pariwisata di Sanur, dibangunlah hotel pertama di Sanur yaitu Hotel Inna Sindhu Beach, kemudian Inna Grand Bali Beach dan Sanur Beach Market. Seiring dengan berkembangnya pariwisata di Sanur, masyarakat yang pada awalnya bermatapencaharian sebagai nelayan mulai merambah menjadi pekerja di sektor pariwisata.

Perubahan mata pencaharian masyarakat juga terjadi di Banjar Sindhu Kaja yang memiliki daya tarik wisata Pantai Sindhu. Pantai ini terletak di Jalan Pantai Sindhu, Kelurahan Sanur Denpasar Selatan. Pantai Sindhu memiliki garis pantai yang sama dengan Pantai Sanur. Pantai ini berpasir putih dengan ombak yang cenderung tenang. Di pantai inilah terdapat hotel pertama di Sanur yaitu Hotel Inna Sindhu Beach. Dalam memenuhi kebutuhan wisatawan, masyarakat setempat membuka usaha seperti art shop, jasa massage dan nail art, ada juga yang membuka warung makanan dan minuman. Usaha art shop di Pantai Sindhu tertata dengan rapi dan membentuk kelompok-kelompok.
Sebagian besar usaha-usaha tersebut dikerjakan oleh kaum perempuan.

Pemberdayaan perempuan pada saat ini merupakan hal yang wajib dilakukan untuk menciptakan keadilan dan kesetaraan gender. Kepedulian akan keadilan dan kesetaraan gender tersebut tertuang dalam Garis Besar Haluan Negara (GBHN) yang pada saat itu dikenal dengan kebijakan peran ganda perempuan. Kebijakan ini berusaha mengubah pemikiran masyarakat bahwa perempuan adalah beban dalam pembangunan. Kebijakan tersebut mengharapkan agar perempuan dapat turut serta dalam pembangunan dengan ikut berperan dalam sektor publik namun tetap menjalankan perannya dalam sektor domestik (Handayani dan Sugiarti, 2002). Banyaknya tuntutan peran yang harus dilakukan oleh perempuan khususnya yang bekerja sebagai pengelola art shop di Pantai Sindhu, sehingga perlu dilakukan sebuah penelitian terkait dengan peran ganda (triple-roles) perempuan.

Tujuannya yaitu untuk mengetahui peran ganda perempuan secara lebih rinci. Manfaat akademis yaitu dapat mengaplikasikan konsep gender. Manfaat praktis yaitu dapat menjadi bahan pertimbangan bagi instansi terkait untuk membuat kebijakan dan strategi pengembangan 
yang lebih berspektif gender sehingga menciptakan keadilan dan kesetaraan gender.

\section{TINJAUAN PUSTAKA}

Gender adalah perbedaan antara laki-laki dan perempuan dalam peran, fungsi, hak, tanggung jawab dan perilaku yang dibentuk oleh tata nilai sosial, budaya dan adat istiadat dari kelompok masyarakat yang dapat berubah menurut waktu serta kondisi setempat. Tanggung jawab dan perilaku yang dibentuk oleh tata nilai sosial, budaya dan adat istiadat dari kelompok masyarakat yang dapat berubah menurut waktu serta kondisi setempat (Puspitawati, 2013). Gender memiliki perbedaan dengan seks. Rincian perebedaan gender dan seks dapat dilihat pada tabel dibawah ini:

Tabel 1. Perbedaan seks dan gender

\begin{tabular}{|c|c|c|c|}
\hline No & Karakteristik & Seks & Gender \\
\hline 1 & $\begin{array}{l}\text { Sumber } \\
\text { Pembeda }\end{array}$ & Tuhan & Manusia (masyarakat) \\
\hline 2 & Visi, Misi & Kesetaraan & Kebiasaan \\
\hline 3 & $\begin{array}{l}\text { Unsur } \\
\text { Pembeda }\end{array}$ & Biologis (alat reproduksi) & Kebudayaan (tingkah laku) \\
\hline 4 & Sifat & $\begin{array}{l}\text { Kodrat, tertentu, tidak dapat } \\
\text { dipertukarkan }\end{array}$ & Harkat, martabat dapat dipertukarkan \\
\hline 5 & Dampak & $\begin{array}{l}\text { Terciptanya } \\
\text { kesempurnaan, } \\
\text { kedamaian, denikmatan, } \\
\text { menguntungkan kedua belah } \\
\text { pihak. }\end{array}$ & $\begin{array}{l}\text { Terciptanya norma-norma/ketentuan } \\
\text { tentang "pantas" atau "tidak pantas". Sering } \\
\text { merugikan salah satu pihak, umumnya } \\
\text { adalah perempuan. }\end{array}$ \\
\hline 6 & Keberlakuan & $\begin{array}{l}\text { Sepanjang masa, dimana saja, } \\
\text { tidak mengenal perbedaan } \\
\text { kelas. }\end{array}$ & $\begin{array}{l}\text { Dapat berubah, musiman dan dapat } \\
\text { berbeda antara kelas. }\end{array}$ \\
\hline
\end{tabular}

Sumber: Handayani dan Sugiarti (2002)

Menurut Soekanto (1990) peran adalah aspek dinamis dari kedudukan (status). Apabila seseorang melaksanakan hak dan kewajibannya sesuai dengan kedudukannya, maka dia menjalankan suatu peran. Moser seperti dikutip dalam Puspitawati (2013) mengatakan bahwa peran perempuan biasanya mengacu pada "Model Tiga Peranan" (Triple Roles Models) yang terdiri dari:

1. Peran produktif, menyangkut kegiatan yang langsung menyumbangkan pendapatan keluarga, tanpa melihat apakah kegiatan tersebut dibayar atau tidak dibayar.

2. Peran reproduktif, menyangkut kelangsungan hidup manusia dan keluarga

3. Peran sosial atau kemasyarakatan, mencakup kegiatan yang tidak terbatas pada pengaturan rumah tangganya tetapi juga pada komunitasnya.
Penelitian sebelumnya yang dilakukan oleh Tirtayani (2007). Penelitian tersebut mengkaji bahwa Bali tak hanya menyimpan potensi wisata, namun juga potensi pembelajaran bagi kaum wanita khususnya dalam memerankan diri dalam lingkup rumah tangga maupun publik. Tidak dimungkiri bahwa peran ganda selalu menyertakan konflik, maka sebagai wanita Bali yang terikat pada adat tentunya dituntut lagi keseimbangan, karena harus menjalankan tiga peran (triple-roles) sekaligus, yakni: (1) peran rumah tangga, (2) peran ekonomi, dan (3) peran adat baik di keluarga, banjar maupun di desa adat.

Penelitian yang dilakukan oleh Arimbawa (2014) yang meneliti kontribusi perempuan Bali pekerja art shop di DTW Tanah Lot terhadap keluarga batihnya. Dari penelitian ini dapat diketahui bahwa perempuan penjaga art shop memberikan kontribusi yang besar 
terhadap kesejahteraan dan kualitas hidup keluarganya. Berdasarkan status pernikahan, perempuan Bali penjaga art shop memiliki jumlah kontribusi yang berbeda-beda terhadap keluarga batihnya. Kapasitas dalam pengambilan keputusan ada dua jenis yaitu perempuan memiliki wewenang sepenuhnya dan pengambilan keputusan dilakukan secara musyawarah antara perempuan dan suaminya. Dari penelitian tersebut dapat diketahui bahwa perempuan yang berkontribusi terhadap pendapatan keluarga mulai diperhitungkan dalam tahap pengambilan keputusan di keluarga batihnya.

\section{METODE}

Jenis yang digunakan yaitu data kualitatif dan kuantitatif. Data kualitatif berupa rincian kegiatan perempuan yang menyumbangkan pendapatan pada keluarga, kegiatan yang dilakukan perempuan demi kelangsungan hidup keluarga, kegiatan perempuan dalam organisasi art shop dan Banjar masing-masing. Sumber data yaitu data primer dan sekunder. Data tersebut didapatkan melalui teknik wawancara mendalam dan observasi. Teknik penentuan informan dilakukan secara snowball sampling, informan yang dipilih pertama yaitu ketua organisasi Sindhu Beach Market kemudian beberapa perempuan pemilik art shop yang mengelola art shop nya sendiri maupun bersama suami. Analisis data dilakukan dengan analisis data lapangan model Miles dan Huberman. Menurut Miles dan Huberman (dalam Sugiyono, 2014) menyebutkan bahwa aktivitas dalam analisis data yaitu reduksi data, penyajian data, penarikan kesimpulan atau verifikasi.

\section{Ruang Lingkup Penelitian}

Batasan lokasi yaitu di Pantai Sindhu. Lokasi ini dipilih karena daya tarik wisata pantai di Kawasan Sanur ini merupakan lokasi awal berkembangnya usaha art shop di Sanur. Ruang lingkup dari permasalahan penelitian ini yaitu tingkah laku yang diharapkan dari status sosial perempuan yang bekerja sebagai pengelola art shop di Pantai Sindhu. Peran tersebut dilihat dari :

1. Peran produktif, yaitu rincian kegiatan perempuan dalam usaha art shop yang menyumbangkan pendapatan pada keluarga.
2. Peran reproduktif, yaitu pekerjaan rumah tangga yang dilakukan perempuan demi kelangsungan hidup keluarga.

3. Peran sosial atau kemasyarakatan, yaitu kegiatan perempuan di organisasi art shop dan Banjar masing-masing.

\section{HASIL DAN PEMBAHASAN}

Banjar Sindhu Kaja merupakan salah satu bagian dari Desa Pakraman Intaran Kelurahan Sanur. Perkembangan pariwisata juga dirasakan masyarakat di Banjar Sindhu Kaja. Di Banjar ini terdapat dua pantai yaitu Pantai Segara Ayu dan Pantai Sindhu. Atraksi yang ditawarkan yaitu berupa keindahan pantai, matahari terbit dengan pemandangan Gunung Agung dan Pulau Nusa Penida dari kejauhan. Kegiatan lain yang dapat dilakukan yaitu berjemur, berenang, memancing ataupun snorkeling.

Kios art shop pertama kali dibangun pada tahun 1966 di Pantai Segara, awalnya hanya berjumlah empat kios namun dengan jumlah pedagang hingga lima orang dalam satu kios. Berdasarkan wawancara dengan ketua organisasi kios souvenir, saat ini berkembang 34 kios dengan jumlah pedagang 60 orang. Begitu pula di wilayah sebelah selatan. Kios art shop juga berkembang sekitar tahun 1980-an yang saat ini memiliki 101 kios art shop dan jasa massage. Melihat perkembangan jumlah pedagang yang semakin banyak maka dibuatlah organisasi untuk mengatur pedagang-pedagang tersebut. Salah satunya yaitu Sindhu Beach Market.

Organisasinya lebih mengarah seperti sebuah koperasi. Pembuatan peraturan, pengurusan keuangan organisasi dan hal lain yang terkait dengan internal organisasi diatur sendiri tanpa adanya campur tangan pihak luar. Anggota organisasi menjadi anggota karena kemauan sendiri, mereka menyadari bahwa mereka merupakan bagian dari Sindhu Beach Market. Dengan adanya organisasi, maka anggota memiliki kesempatan berusaha seluasluasnya namun tetap mengikuti aturan yang berlaku demi kebaikan bersama.

Berdasarkan hasil wawancara, rata-rata usia perempuan pengelola art shop di Sindhu Kaja yaitu usia 35-50 tahun dan sudah menikah. Besarnya tuntutan ekonomi saat ini, menyebabkan kaum perempuan juga harus ikut 
andil dalam mencari penghasilan. Membuka usaha art shop tidak memandang tingkat pendidikan dan tidak memerlukan kompetensi khusus. Alasan para perempuan membuka kios art shop bukan hanya karena mereka tidak mempunyai pendidikan dan keahlian yang tinggi tetapi karena tuntutan peran mereka dalam lingkup rumah tangga dan masyarakat. Jika menjadi karyawan di industri pariwisata seperti hotel dan restoran mereka tidak memiliki kebebasan waktu untuk menjalankan semua perannya karena sebagai karyawan dituntut untuk mematuhi peraturan di tempat kerja. Jam kerja, jam pulang kerja dan waktu libur akan diatur oleh atasan di tempat kerja. Berikut adalah tabel uraian peran sosial dan ekonomi perempuan pengelola art shop di Pantai Sindhu:

Tabel 2 Triple Roles Perempuan pengelola Art shop di Pantai Sindhu

\begin{tabular}{|c|c|c|}
\hline Peran Produktif & Peran Reproduktif & Peran Sosial \\
\hline $\begin{array}{l}\text { Membuka usaha art shop } \\
\text { dan jasa massage. } \\
\text { Kegiatannya meliputi : } \\
\text { 1. Menentukan sumber } \\
\text { modal usaha } \\
\text { 2. Menentukan besar } \\
\text { usaha dan jumlah } \\
\text { barang yang dijual. } \\
\text { 3. Menentukan harga } \\
\text { jual. } \\
\text { 4. Menentukan waktu } \\
\text { bekerja. } \\
\text { 5. Mengelola pendapatan } \\
\text { dan keuntungan } \\
\text { 6. Menentukan } \\
\text { penggunaan } \\
\text { keuntungan usaha. }\end{array}$ & $\begin{array}{l}\text { Melakukan kegiatan rumah tangga } \\
\text { seperti: } \\
\text { 1. Memasak dan menyiapkan } \\
\text { makanan } \\
\text { 2. Berbelanja } \\
\text { 3. Membersihkan rumah dan } \\
\text { perabotan } \\
\text { 4. Mencuci dan menyetrika pakaian } \\
\text { 5. Mengasuh anak } \\
\text { 6. Menyiapkan sarana upacara dan } \\
\text { Mebanten }\end{array}$ & $\begin{array}{l}\text { Ikut berperan kegiatan di dalam } \\
\text { masyarakat dan kelompok, yaitu: } \\
\text { 1. Organisasi Beach Market } \\
\text { Perannya berupa : } \\
\text { a. Membuat kesepakatan } \\
\text { bersama kelompok dan } \\
\text { menaati aturan-aturan } \\
\text { kelompok. } \\
\text { b. Membayar iuran bulanan } \\
\text { dan membayar pinjaman. } \\
\text { 1. Banjar/Desa Adat: } \\
\text { a. Ngayah } \\
\text { b. Berkunjung dan menolong } \\
\text { anggota adat yang } \\
\text { mempunyai kegiatan } \\
\text { Manusa Yadnya dan Pitra } \\
\text { Yadnya. } \\
\text { 2. PKK } \\
\text { a.Arisan } \\
\text { b. Latihan menabuh } \\
\text { gambelan. }\end{array}$ \\
\hline
\end{tabular}

Sumber: Olahan data primer, 2014

\section{Peran Produktif}

Kegiatan membuka kios art shop digunakan untuk mengisi waktu luang dan sekedar menambah uang untuk kebutuhan sehari-hari. Bagi perempuan, bekerja membuka kios art shop tidaklah mengganggu perannya dalam rumah tangga dan di masyarakat karena kegiatan berjualan di art shop itu santai. Tipe kepengurusan kios art shop dibagi menjadi dua yaitu dilakukan sendiri oleh perempuan dan bersama dengan suami.

Kegiatan yang dilakukan oleh perempuan yang mengelola sendiri, yaitu mulai dari mencari modal, mengontrak tempat, mencari barang, menentukan harga dan menjualnya. Semua kegiatan itu dilakukan sendiri tanpa campur tangan suami. Penghasilan yang didapat dari membuka art shop yaitu ratarata tiga juta per bulan. Penentuan penggunaan hasil usaha bagi perempuan yang mengelola art shop sendiri, dilakukan oleh mereka sendiri. Hasil usaha mereka akan digunakan untuk biaya kecil-kecil seperti ke dapur dan biaya sarana persembahyangan seperti membeli canang dan upakara untuk hari raya. Suami tetap berperan sebagai pencari nafkah utama. Biaya yang termasuk besar seperti biaya sekolah anak, biaya kesehatan, cicilan elektronik dan 
sebagainya adalah tanggung jawab suami. Sisa uang hasil keuntungan mereka akan ditabung untuk keperluan penting dan mendesak. Dengan bekerja, perempuan merasa lebih berguna, bisa membantu ekonomi keluarga dan bisa membeli apa yang dia inginkan tanpa menunggu uang dari suaminya.

Pembagian peranan terjadi dalam pengelolaan.Pengelolaan art shop yang dilakukan perempuan bersama dengan suami. Modal usaha berasal dari suami. Pembelian barang yang akan dijual dan penentuan harga ditentukan oleh perempuan sendiri. Penentuan penggunaan keuntungan usaha dirundingkan bersama suaminya. Walaupun bekerja bersama suami mengelola satu art shop, perempuan tetap memiliki peran yang sama kuat dengan suaminya. Tidak ada yang mendominasi satu sama lainnya. Semua keputusan disepakati bersama-sama. Terdapat perbedaan dalam penggunaan hasil usaha untuk keperluan pribadi. Jika mengelola sendiri, penghasilan bisa digunakan sesuai dengan keputusan sendiri. Penghasilan yang didapatkan dari mengelola art shop bersama suami adalah penghasilan bersama sehingga memerlukan izin dan perundingan terlebih dahulu bersama suami.

\section{Peran Reproduktif}

Peran perempuan dalam rumah tangganya yaitu memasak membersihkan rumah dan perabot rumah tangga, mencuci dan menyetrika pakaian, berbelanja, mengasuh anak dan menyiapkan sarana upacara. Berbelanja, memasak, membersihkan rumah dilakukan sebelum membuka kios. Pembagian kerja antara perempuan dan suaminya dilakukan jika memiliki anak-anak berumur dibawah 12 tahun. Saat perempuan mengerjakan tugas rumahnya, laki-laki bertugas mengantarkan anak ke sekolah dan menjemputnya lagi di siang hari. Pengambilan peran mengantar anak ke sekolah oleh suami ini membuat peran perempuan reproduksi perempuan menjadi lebih ringan.

Banyaknya peran yang harus dilakukan oleh perempuan dirumah tangganya dan peran bekerja mencari nafkah membuat perempuan harus pandai mengatur waktu. Jika tidak sempat, pekerjaan seperti memasak tidak dilakukan dan akan membeli lauk siap santap di pasar. Begitu juga dengan mencuci baju, jika tidak sempat maka akan diserahkan pada jasa binatu. Untuk saat ini laki-laki belum mau mengambil peran tersebut. Sarana persembahyangan sehari-hari seperti canang mereka juga dibeli di pasar. Hal itu berdasarkan pertimbangan kepraktisan dan efisiensi waktu. Dalam mengisi waktu luang di art shop , Pekerja perempuan disini juga membawa bahan-bahan jejahitan dari rumah dan dikerjakan di art shop untuk perlengkapan banten upacara atau hari raya.

Fenomena perempuan yang bekerja ini menyebabkan bertambahnya usaha-usaha yang membantu meringankan peran reproduktif perempuan seperti usaha laundry, penjual canang atau banten, penyedia jasa pembantu rumah tangga dan pengasuh anak. Namun menjamurnya usaha-usaha tersebut tidak menyebabkan pekerja perempuan menyerahkan semua peran domestiknya pada orang lain. Walaupun bekerja, pekerja perempuan di sektor informal pariwisata di Sindhu Kaja sangat pandai dalam mengatur waktu dan pekerjaanya untuk tetap dapat menyelesaikan perannya sebagai seorang ibu rumah tangga. Hal itu didukung dengan waktu bekerja yang bisa diatur sendiri tidak terikat pada atasan.

\section{Peran Sosial/Masyarakat}

Selain menjalankan peran reproduktif dan peran produktif, perempuan Bali khususnya juga mempunyai peran dalam masyarakat. Sebagai bagian dari kelompok, perempuan juga memiliki peran dalam kelompoknya. Suryati merupakan Ketua dari organisasi Sindhu Beach Market. Sebagai ketua, dituntut untuk memberikan teladan bagi pekerja lainnya. Membuat aturan berdasarkan kesepakatan bersama dan memastikan tidak ada konflik yang dapat menngganggu kenyamanan wisatawan adalah tugasnya. Sebagai anggota organisasi, perempuan berkewajiban untuk mengikuti kesepakatan yang diterapkan organisasi. kegiatan anggota seperti membayar iuran bulanan, menjaga kebersihan, membayar pinjaman uang di organisasi dan mengawasi pekerja satu sama lain agar tidak ada yang melanggar peraturan.

Diluar organisasi Sindhu Beach Market mereka adalah warga Banjar Adat yang mempunyai tugas untuk mematuhi ketentuan adat. Mengikuti kegiatan ngayah, berkunjung ke rumah dan membantu pekerjaan anggota banjar yang mempunyai kegiatan Manusa Yadnya dan Pitra Yadnya adalah sebuah kewajiban. Selain itu, mereka juga merupakan anggota PKK. 
Kegiatan yang dilakukan berupa arisan dan latihan menabuh. Jika ada kegiatan yang berbenturan dengan kegiatan lain, maka salah satu kegiatan akan dikorbankan namun tidak sampai mengorbankan kegiatan adat. Seperti kutipan hasil wawancara kepada Suryati di bawah ini:

"urusan adat tetap harus dijalankan.

Kalau ada acara kundangan atau ngayah ya itu dikerjakan dulu. Biasanya kalau ada kegiatan adat jam dua baru buka art shop nya, kalau sibukya ditutup aja".

Kegiatan bekerja tidak membuat para perempuan meninggalkan perannya dalam masyarakat adat. Perempuan akan mengatur waktu antara ngayah dan bekerja agar keduanya dapat berjalan. Adanya tuntutan peran untuk mencari uang tidak membuat para perempuan menjadi money oriented dan melupakan perannya dalam masyarakat adat. Walaupun kegiatan berjualan mendatangkan pendapatan, jika pada waktu yang bersamaan ada kegiatan adat, pekerja perempuan tetap menomorsatukan adat. Hal itu dikarenakan kegiatan adat sangat berkaitan dengan agama dan nama baik di mata masyarakat adat.

\section{KESIMPULAN}

Triple roles perempuan pengelola art shop di Pantai Sindhu terdiri dari peran produktif yaitu: menentukan sumber modal usaha, menentukan besar usaha dan jumlah barang yang dijual, menentukan harga jual, menentukan waktu bekerja, mengelola pendapatan dan keuntungaa, menentukan penggunaan

\section{Daftar Pustaka}

Arimbawa. 2014. Kontribusi Perempuan Bali Penjaga Art shop terhadap Keluarga Batih. Tugas akhir pada Program Studi Destinasi Pariwisata Fakultas Pariwisata Universitas Udayana.

Handayani,Trisakti dan Sugiarti. 2002. Konsep dan Teknik Penelitian Gender. Malang: UMM press.

Puspita, H. 2012. Gender dan Keluarga. Bogor: PT IPB Press.

Putri, Noviarina Purnami. 2011. Wanita Di Sektor Informal Peran Dan Kedudukannya Dalam Rumah Tangga (Studi Kasus Pada Pekerja Wanita Di Industri Jamur Desa Hargobinangun Kecamatan Pakem). Prosiding keuntungan usaha; peran reproduktif yaitu: memasak dan menyiapkan makanan, berbelanja, membersihkan rumah dan perabotan, mencuci dan menyetrika pakaian, mengasuh anak menyiapkan sarana upacara dan mebanten, peran sosial atau masyarakat di organisasi beach market yaitu: membuat kesepakatan bersama kelompok dan menaati aturan-aturan kelompok dan membayar iuran bulanan dan membayar pinjaman, di banjar/desa adat yaitu: ngayah, berkunjung dan menolong anggota adat yang mempunyai kegiatan manusa yadnya dan pitra yadnya dan di Kelompok PKK yaitu: arisan dan latihan menabuh gambelan. Peran produktif tidak sampai membuat peran lainnya terhambat. Semua dapat berjalan dengan baik karena perempuan yang membuka usaha art shop di Pantai Sindhu dapat mengatur waktu kerja sesuai keinginan sendiri.

Rekomendasi yang dapat diberikan yaitu, sebaikya pemerintah mendukung para perempuan untuk membuka usaha sediri seperti mengadakan pelatihan-pelatihan dan membantu permodalan. Sebaiknya semua lapisan masyarakat menjunjung tinggi kesetaraan dan keadilan gender, karena perempuan yang bekerja memiliki kontribusi besar terhadap pendapatan keluarga. Penelitian selanjutnya diharapkan mampu melihat peran perempuan secara lebih mendalam seperti pemaknaan peran, dampak yang ditimbulkan akibat perempuan bekerja dan dukungan program pembangunan dalam meningkatkan pemberdayaan perempuan akan menjadi isu yang sangat menarik untuk dikaji.

Seminar Nasional Hasil Penelitian. Jurusan Sosial Ekonomi Fakultas Pertanian Universitas Gajah Mada

Soekanto, Soerjono. 2009. Sosiologi Suatu Pengantar. Jakarta: PT Raja Grafindo Persada.

Sugiyono. 2014. Metode Penelitian Kuantitatif Kualitatif dan $R$ \& D. Bandung: Alfabeta.

Tirtayani, Luh Ayu. 2007. Wanita Bali dalam Pemaknaan Peran (Studi Fenomenologis terhadap Triple-Roles Wanita Bali, di Desa Adat Kuta). Tesis pada Universitas Diponegoro. 